\title{
PEMBUATAN ZAT PEWARNA NABATI DARI KUNYIT
}

Oleh:

Ir. Budi Utami *)

\begin{abstract}
Turmeric is useful as medicine, spices and pigment. A plant cultivated extensively in India, Ceylon and Indonesia.

Turmeric pigment consist of the dried, boiled and grinded rhixomes of Curcuma longa.

Turmeric pigment have more benefit than synthetic pigment.
\end{abstract}

\section{PENDAHULUAN}

Karena banyaknya macam warna, manusia telah merasa perlu memberi istilah atau nama yang berbeda-beda pada setiap warna yang dikenalnya. Keperluan membedakan warna itu terdapat dalam dunia perbatikan, untuk memperoleh masing-masing warna itu dengan tepat maka perlu menguasai teknologi. Warnanyalah yang pertama kali menarik mata dan perhatian serta memikat sang pembeli. Selain dalam dunia pembatikan, pewarnaan juga mempunyai peranan sangat penting dalam kerajinan anyam-anyaman serta bahan makanan sehingga penggunaan zat pewarna turut menentukan kelengkapan tata cara yang harus diperhatikan. Pada saat ini di negara-negara industri maju zat pewarna alami praktis sudah tidak mempunyai nilai ekonomi yang penting lagi, karena semakin banyaknya perusahaan industri kimia yang memproduksi zat pewarna sintetis untuk berbagai keperluan sehingga mampu mendesak industri zat pewarna alami. Akan tetapi timbulnya gerakan kembali ke alam, ketakutan akan pengaruh pencemaran oleh zat pewarna tersebut.

Tanaman kunyit merupakan tanaman tropika dan dapat dijumpai di Indonesia, Sri Langka dan India. Nama lain dari tumbuhan ini adalah Curcuma domestica, tanaman ini banyak tumbuh di kebun ataupun di hutan jati, termasuk suku Zingiberaceae. Tumbuhan kunyit ini berupa herba yang tingginya dapat mencapai sampai 1 meter. Tumbuhan ini tidak berbulu dan mempunyai warna hijau, bunganya pucat dan pada pangkalnya berwarna kuning. Daun pelindungnya berwarna putih, sedangkan daging rimpangnya berwarna kuning tua. Tumbuhan ini mudah diperbanyak dengan jalan menyetek rimpangnya yang sudah cukup tua. Biasanya penyetekan ini dilakukan pada waktu tanam pada awal musim hujan dan dapat juga dengan tunas-tunasnya. Biasanya ditanam sebagai tumpang gilir dengan ditumpangsarikan dengan tanaman sayuran. Meskipun bunga kunyit terbentuk, tapi bijinya tidak kita dapati.

Di Indonesia pemanfaatan kunyit dipakai sebagai obat, rempah-rempah atau bumbù dan zat pewarna. Kunyit selain memberikan warna kuning mempunyai fungsi sebagai pengawet/anti bakteri, karena kunyit mengandung kurkumin yaitu senyawa anti bakteri. Kunyit juga mengandung minyak atsiri, kandungan lainnya berupa damar, gom, lemak, protein dan vitamin C. 


\section{ZAT PEWARNA NABATI}

Banyak sekali jenis tumbuhan yang dipergunakan sebagai sumber zat pewarna, misalnya Pleomele angustifolia atau suji, perasan daun untuk memberi warna hijau pada makanan. Pada umumnya zat pewarna tadi diperoleh dengan cara membuat ekstrak tumbuhannya, maka warna yang dihasilkan dalam berbagai ulangan pembuatan tidaklah akan sama benar. Banyak sekali faktor yang berasal dari tumbuhannya sendiri, ataupun dari iklim dan lingkungan hidup, serta penyediaan dan proses pembuatan zat pewarnanya yang akan
menyulitkan pembakuan.

Kesulitan membakukan corak, kecermelangan dan kepekatan warna yang ditimbulkan oleh sesuatu zat pewarna nabati merupakan indikasi keluasan spektrum warna yang dapat dihasilkannya. Dengan perubahan perlakuan sedikit saja dan proses penyediaannya (misalnya kadar bahan yang dipakai), sudah pasti akan menghasilkan corak warna dengan kepekatan yang berbeda-beda.

Zat pewarna kuning diekstrak dari rimpang kunyit dan kerabat-kerabat dekatnya (curcuma), serta disukai orang karena dapat mewarnai kapur, sutra dan wol tanpa harus menggunakan penyaren. Akan tetapi zat pewarna yang memberikan corak kuning terbaik ini bersifat luntur dan tidak tahan terhadap cahaya, sabun dan pencucian. Untuk mengatasinya dalam pembatikan orang menambahkan perasan jeruk, pepagan mangga, tawas atau cuka. Di barat orang memakainya bersama zat pewarna lain untuk menghasilkan deretan corak coklat dan hijau lumut. Dalam industri rumah tangga zat pewarna ini banyak dipakai dalam masak memasak ataupun untuk mewarnai bahan anyaman bambu, pandan dan mendong. Dalam kasus terakhir ini adakalanya ditambahkan kapur untuk mendapatkan warna yang lebih gelap.

\section{PEMBUATAN ZAT PEWARNA KUNYIT}

Dibuat dengan membersihkan dan merebus umbi akar tanaman kunyit. Umbi akar (Rhizome) yang telah dipatah-patahkan dari umbi induknya (empu) dicuci dan ditempatkan pada panci (bejana besi) atau dalam periuk tanah liat, ditambah air secukupnya sampai permukaan kunyit terendam air, kemudian dimasak dengan api kecil sampai mendidih dan lunak dibutuhkan waktu kira-kira antara 1 sampai 2 jam. Cara memeriksa apakah kunyit sudah masak atau belum seperti cara untuk memeriksa kemasakan kentang, dengan ditusuk lidi tersebut dapat menembus dengan mudah berarti kunyit telah masak. Pemasakan yang kelewat masak atau kurang masak harus dihindarkan karena akan menurunkar atau mengurangi hasilnya. Kunyit kemudian diangkat dari bejana pemasakan, diletakkan merata pada tempat penjemuran supaya kering. Pada penjemuran ini harus sering kali dibalik-balik. Pada malam hari kunyit dikumpulkan dan ditutup, penjemuran berlangsung kurang lebih 10 hari.

Bila sudah kering betul, kulitnya mudah terkelupas bila digosok. Untuk menghilangkan kulitnya digosok dengan tangan, dapat juga diputar dalam polishing drum. Kunyit yang sudah kering dan bersih dari kulitnya, digiling
dan selanjutnya diayak. 
Percobaan dilakukan dengan memakai kunyit basah sebanyak $6 \mathrm{~kg}$ dan kadar air $=39,585 \%$. Waktu pemasakan sehingga didapat kunyit yang lunak (masak) dibutuhkan waktu 1 jam. Setelah penjemuran 10 hari dalam panas matahari kadar air kunyit $=6,38 \%$ dan rendemen hasil percobaan $10 \%$. Selanjutnya kunyit dijadikan bentuk serbuk dengan ukuran 100 mesh.

\section{Alat Pembuang Kulit "Polishing Drum".}

Mula-mula alat ini dibuat dari tong kayu yang tertutup pada kedua sisinya. Dilengkapi dengan pintu kecil $(15-23 \mathrm{Cm})$. Pada badan tong diberi lubanglubang kecil dengan garis tengah kurang lebih $0,65 \mathrm{Cm}$. Alat ini diberi poros (as) dari besi yang cukup panjang sehingga memungkinkan untuk menaikkan posisi tong dari kedua sisinya. Pada salah sisi tong diberi handle pemutar yang dapat menggerakkan porosnya.

Kemudian diadakan perubahan dan perbaikan polishing drum. Pada alat ini tong dibuat dari besi (logam) yang kuat dan dirol/dilengkungkan. Alat tersebut diberi lubang-lubang yang cukup besar dan dilengkapi dengan handle pemutar pada kedua sisinya. Dengan demikian pengisian dan pengosongan dapat dilakukan pada masing-masing sisi-sisi. Karena umbi akar kunyit kecil-kecil dapat lepas menembus polishing drum, maka alat tersebut diberi bungkus dengan anyaman kawat yang kuat berbentuk seperti jala (saringan). Dengan demikian kunyit dapat tertahan, tetapi cukup mudah untuk lewatnya debu, kotoran dan akar-akar serabut selama pengoperasian drum.

Spesifikasi polishing drum,

- Panjang $=61 \mathrm{Cm}$

- Garis tengah $=91,5 \mathrm{Cm}$

- Muatan $\quad=175 \mathrm{~kg}$ kunyit yang sudah direbus dan kering.

- R.P.M. $\quad=30$

\section{KEUNTUNGAN PENGGUNAAN ZAT PEWARNA KUNYIT DIBANDING- KAN DENGAN ZAT PEWARNA SINTETIK.}

Dalam pengetrapan percobaan dilakukan terhadap makanan tahu, karena dalam kenyataan penggunaan zat pewarna kunyit ini banyak kita jumpai pada makanan tahu, ayam, tempe dan lain-lainnya. Tahu juga banyak dikenal oleh masyarakat kita dan harganya relatif murah.

Percobaan dilakukan dengan memakai variabel:

1. Waktu perendaman: 5, 10, 15, 20 menit

2. Jumlah zat pewarna

- Sintetik : $1 \mathrm{~g} / 500 \mathrm{cc}$

- Tepung : $1 \mathrm{~g} / 500 \mathrm{cc}, 2 \mathrm{~g} / 500 \mathrm{cc}, 3 \mathrm{~g} / 500 \mathrm{cc}, 4 \mathrm{~g} / 500 \mathrm{cc}, 5 \mathrm{~g} / 500 \mathrm{cc}$ dan $6 \mathrm{~g} / 500 \mathrm{cc}$.

3. Macam zat pewarna

- Zat pewarna kunyit : hasil percobaan sendiri

- Zat pewarna sintetik : yang beredar di pasaran. 


\section{Prosedure Percobaan.}

1. Zat pewarna baik sintetik maupun kunyit masing-masing dilarutkan de-

2. Tahu putih (yang belum dalam larutan pewarna tersebut warna) dicuci, selanjutnya direndam

3. Setelah perendaman, tahu dibiarkana beberapa menit sesuai vabel. mengetahui keuntungan perarkan sampai beberapa malam untuk

Hasil Percobaan.

1. Warna tahu setelah perendaman dalam larutan pewarna kunyit baik

2. Jumlah larutan pewarna kunyit pada tahu memberikan corak warna kuning yang berbeda-beda, seperti:

$4 \mathrm{~s} / \mathrm{d} 5 \mathrm{~g} / 500 \mathrm{cc}$ menghasilkan warna kuning sedang.
$6 \mathrm{~g} / 500 \mathrm{cc}$

3. Keadaan tahu setelah diwasilkan warna kuning tua.

punyai perbedaan antara yang dan penginapan beberapa malam memzat pewarna kunyit, tahu yang menggui zat pewarna sintetik dengan baik/tahan, karena kunyit mengandung zat anti zat pewarna kunyit lebih

\section{KESIMPULAN}

1. Dalam pembuatan zat pewarna kunyit waktu yang diperlukan untuk petelah pengering didapat kunyit yang masak dibutuhkan waktu 1 jam. kunyit yang kering dan bersih dari dalam sinar matahari maka didapat kadar air kunyit 6,38\%.

2. Hasil

- Jumlah zat pewarna yang kunyit pada makanan tahu sebagai berikut: larutkan 4 - 5 g tepung kunyit berikan warna yang baik dengan me-

- Waktu perendaman tidak berpe dalam $500 \mathrm{cc}$.

- Pemakaian zat pewarna kunyit paduh sekali. untungan dibandingkan dengan pada makanan tahu mempunyai ketahan karena kunyit mengandung zat pewarna sintetik, tahu akan lebih 


\section{DAFTAR PUSTAKA}

1. OSWALD T. TAMPUBOLON, DRS APOTEKER $\ldots \ldots \ldots \ldots \ldots \ldots \ldots$, Tumbuhan obat.

Lembaga Biologi Nasional - LIPI

Bogor.

2. MIEN A. RIFAI . . . . . . . . . . . . . . . . . Tetumbuhan Penghasil Pewarna Alami Indonesia.

Herbarium Bogoriense, Bogor.

Konggres Ilmu Pengetahuan Nasional IV tahun 1986.

3. MINISTRY OF OVERSEAS DEVELOPMENT

Note on The Preparation of Turmeric.

October, 1962

Tropical Products Institute. 